\title{
Evaluative state, nation-state: a last hurrah?
}

\author{
Guy Neave
}

\begin{abstract}
The paper takes a resolutely historical and political perspective in analysing the rise of the Evaluative State in its European setting. He traces the development of four versions of the Evaluative State from its origins in the mid to late Eighties in terms of two stages: first, its operational purpose, second, its subsequent re-definition of ownership and role in steering higher education policy. Focusing primarily on the three pioneering systems - France, the United Kingdom, the Netherlands and later Portugal, the author argues that the present dynamic of the Evaluative State marks a major step in the history of higher education policy. If today the Evaluative State acts as the prime instrument of economic Liberalism as the common basis of European higher education policy, its purpose in the original setting of Nation-State was very different. Such differences are examined, and the impact of the Evaluative State weighed up in its various forms.
\end{abstract}

\section{Keywords:}

evaluative State; higher education policy; system steering; policy control and the nation-state. 


\section{Estado Avaliador, Estado Nação: Um Último "Viva”?}

Resumo: Este artigo assume uma perspetiva decididamente histórica e política na análise da ascensão do Estado Avaliador no seu contexto europeu, descrevendo o desenvolvimento de quatro versões do Estado Avaliador desde as suas origens, de meados ao fim da década de oitenta do século passado, em termos de dois momentos: primeiro, o seu objetivo operacional, segundo, a sua subsequente redefinição de apropriação e papel na condução das políticas do ensino superior. Colocando o enfoque primordialmente nos três sistemas pioneiros - França, Reino Unido e Holanda, e mais tarde Portugal, o autor defende que a atual dinâmica do Estado Avaliador constitui um passo importante na história das políticas do ensino superior. Se hoje o Estado Avaliador age como instrumento do Liberalismo económico como a base comum das políticas europeias do ensino superior, o seu intuito no contexto original do Estado-Nação era muito diferente. Estas diferenças são analisadas, e o impacto do Estado Avaliador é ponderado nas suas várias formas.

Palavras-chave: estado avaliador; políticas de ensino superior; condução do sistema; controlo de políticas e o Estado-Nação.

\section{L’Etat évaluateur, l'État-Nation: Un dernier "Ça va"?}

Résumé: Cet article adopte une perspective résolument historique et politique de l'analyse de la montée de l'État évaluateur dans le contexte européen, décrivant le développement de quatre versions de l'État évaluateur depuis ses origines, de la moitié vers la fin des années 80 du siècle dernier, en ce qui concerne deux moments : premièrement, son objectif opérationnel, second, sa redéfinition subséquente de l'appropriation et rôle dans la conduite des politiques de l'enseignement supérieur. En mettant l'accent principalement sur les trois systèmes pionniers -France, Royaume-Uni, Hollande, et plus tard, le Portugal. L'auteur soutient que la dynamique actuelle de l'Etat évaluateur est une étape importante dans l'histoire des politiques de l'enseignement supérieur. Si aujourd'hui l'État évaluateur agit comme un instrument du Libéralisme économique comme la base commune des politiques européennes de l'enseignement supérieur, son objectif le contexte original de l'État-nation était très différent. Ces différences sont analysées, et l'impact de l'État évaluateur est considéré dans ses diverses formes.

Mots clés: État évaluateur; politiques de l'enseignement supérieur; système d'entraînement; contrôle de politiques et l'État-nation.

\section{Estado Evaluador, Estado Nación: ¿Un Último "Viva”?}

Resumen: Este artículo asume una perspectiva decididamente histórica y política en el análisis del ascenso del Estado Evaluador en su contexto europeo, presentando el desarrollo de cuatro versiones del Estado Evaluador desde sus orígenes, de meados al final de la década de los ochenta del siglo pasado, en términos de dos momentos: primero, su objetivo operacional, segundo, su subsecuente redefinición de apropiación y papel en la conducción das políticas de enseñanza superior. Poniendo el foco primordialmente en los tres sistemas pioneros - Francia, Reino Unido y Holanda, e más tarde Portugal, el autor defiende que la actual dinámica del Estado Evaluador constituye un paso importante en la historia de las políticas de enseñanza superior. Se hoy el Estado Evaluador actúa como instrumento del Liberalismo económico como la base común de las políticas europeas de enseñanza superior, su finalidad en el contexto original del Estado Nación era muy distinta. Estas diferencias son analizadas, y el impacto de Estado Evaluador es ponderado en sus varias formas.

Palabras-clave: estado evaluador; políticas de enseñanza superior; conducción del sistema; controlo de políticas y el estado nación. 


\section{Introduction}

Let me claim one small indulgence before we plunge together into the subtle depths and limitless dimensions of the Evaluative State. For many years, I have been remarkably inactive in Comparative Education, stricto sensu. Rather, my stamping ground has been Comparative Higher Education Policy. This in turn has shaped my thinking about the Evaluative State. Here, I will readily admit, is one vast sin of omission. That sin, if not wholly mortal, is the quite deliberate - and utterly culpable - inattention to the consequences the rise of the Evaluative State has had upon both primary and secondary education. I cover my head with dust and ashes. But, I do so with a certain sly confidence. This confidence rests on the intimate conviction that my fellow panellists will, in the phrase of the legendary and deeply illiterate reviewer, "fill a much-needed gap."

\section{A Few Sideswipes}

As a contemporary historian of higher education, I have little patience with such reach-me-down concepts as "path dependency theory." And still less with interpreting the history of higher education, whether at the systems or at the institutional level, (Clark, 1983) in terms of "historical path dependency." To historians, this omnium gatherum, culled from organizational sociology and fortified with the occasional injection of tertiary sources filched from political science, is little better than historical determinism rehashed and spiced up with the reeking aromas of self-fulfilling prophecy, itself attributed to organizational inertia or explained away as corporate reluctance to do other than following the "noiseless tenor of their (institutional) way" (Gray, 1751, Elegy in a Country Churchyard). Still, historical perspectives have their uses. If you want to know where you are going, it is as well to know where you have come from. And why.

\section{The Route Map of this presentation}

Many interpretational perspectives surround the Evaluative State. I will highlight what after three decades of mulling this construct over, appears to me today to be the most revealing and perhaps the most disquieting feature. First, I will dissect the dynamic underlying the Evaluative State in terms of in two phases.

\section{The Evaluative State as the Last Hurrah}

Let me start by making a claim, which may seem bizarre at best and outrageous at worst - more so seeing it comes from a self-exiled Brit in the aftermath of Brexit! Setting the Evaluative State in place has a very specific historical importance. For hindsight 
tells us the Evaluative State was the last major strategic act in higher education policy that the Nation State in Western Europe undertook in all full sovereign independence. True, chronology, conditions and circumstances that attended the rise of the Evaluative State, vary. That is as it should be. Whenever three historians are gathered together, at least four different interpretations raise their heads. Furthermore, complexity is fuelled further by one's personal allegiance, interests, disciplinary training quite apart from the specific and base referential country - or countries - one focuses on (Neave \& Amaral, 2011, pp. 1- 47).

\section{Murky Origins}

Both in its dynamic and the trends underlying it, the Evaluative State differs widely in type, range, impact and purpose from system to system, (Hsien \& Huisman, 2016) Nevertheless, the overall chronological build-up, the establishment of specific agencies, instrumentalities and procedures that together constitute the Evaluative State in Europe, is relatively clear. As Schwartz-Hahn and Westerheijden pointed out, by the end of the Nineties provision for the Evaluative State was in place - or legislated for in virtually all Western European states, though some, like Greece, dragged their feet (Schwartz-Hahn \& Westerheijden, 2004).

\section{Indelicate Oversights}

Today, the Evaluative State stands as one of the prime vehicles for injecting the imperatives of Neo-Liberalism, New Public Management into higher education and with it competitive deflation, market flexibility and de-regulation (Gayon, 2012) It has not always been so. The grafting of an ideological overlay onto the ostensibly pragmatic tasks of 'diagnosing' institutional performance and recommending 'treatment' is, itself the outstanding feature in the dynamic construction of the Evaluative State.

The retrospective, grafting of an ideological overlay onto the Evaluative State gave coherence to an instrumentality the origins of which lay in a series of pragmatic initiatives individual governments undertook to adjust higher education to economic stress on the one hand and its further massification on the other. Only later did the evolving Evaluative State acquire an ideological overlay. It is fair to say, however, that the 'overlay' became as pervasive as the processes, procedures, practices, benchmarks and indicators that constituted the operational dynamic the Evaluative State was set up to define and to enforce in the first place. 


\section{Stage 1: Origins, Scope and Purpose}

In the pioneering systems of, Britain, France and the Netherlands, the first steps in constructing the Evaluative State emerged in the Eighties. They did not - at least to those of us observing the scene at the time - appear at first to herald fundamental change. Rather, we saw them as a shift in priority. Or, to revert to a medical metaphor, they appeared to be a diagnosis. Quality, efficiency and enterprise, the watchwords of the moment, did not seem pose a threat to the basic historic relationship between State and higher education (Neave, 1988). Agreed, the relationship, sometimes described in terms of "state control" in France and the Netherlands, as for most Continental European systems (Neave \& van Vught, 1991) shone by its absence in the UK.

Measures rationalizing higher education provision in the Netherlands - the so called 1981 policy of concentration and task division (Schaalvergroting, Taakverdeling en Concentratie Wetenschappelijk Onderwijs 1983) or the more brutal financial surgery in the United Kingdom of the same year (Kogan \& Kogan, 1983)- dramatic though they were - did not, at first appear to question existing patterns of authority. On the contrary. In Britain, proposals for the closer monitoring of university performance and efficiency came in 1985 from university leadership. (Jarratt Report, 1985) A further initiative from the same source created an audit unit in the then Committee of Vice Chancellors and Principals. Certainly, this could be seen as university leadership setting its own house in order. Significantly, by taking on the functions both of policy 'diagnosis' and treatment, and in proposing to monitor 'quality' in terms of university output indicators, British university leadership sought to retain mastery over the essentials of university autonomy.

\section{Going Dutch}

Paradoxically, the high degree of institutional autonomy British vice chancellors fought tooth and nail to preserve was precisely the model under consideration by both government and universities in the Netherlands. True, the central concept differed. The Dutch envisaged a "cybernetic relationship." This called for the Ministry of Science and Education to confine itself to strategy whilst Universities took over responsibility of implementation, execution. And their demonstration. Under the slogan of "steering at a distance", this arrangement bought about a fundamental shift in State university relations. More to the point, it conferred on the Vereeniging der Samenwerkende Nederlands Universiteiten (the Union of Cooperating Dutch Universites or VSNU), the main forum for Dutch universities, the responsibility for regular monitoring and feedback on quality and institutional performance. The rationale of the Dutch version of the 
Evaluative State sought to 'free up' - and thus speed up - institutional responsiveness to market change. It did so by extending the sphere of institutional initiative on the one hand and reinforcing accountability and adaptation on the other (Scheele, Maassen \& Westerheijden, 1998).

\section{A French Perspective}

In France, however, as the late Burton R. Clark used to say, 'everything was different.' The issue government sought to tackle was politically fraught. For though France did not, at the time, face budgetary restrictions, it nevertheless faced a formidable dilemma: how to speed up the pace of change without incurring the literally riotous veto of the Student Estate? The creation of the Comité National d'Evaluation in 1984 (Staropouli, 1987, pp.127-131) was the first clear legislative act in Europe to drive towards the Evaluative State (Neave, 1996). It was a delicate balancing act - as events three years later showed with a vengeance. In 1987, the Right wing government of Jacques Chirac sought to introduce selective entry to France's universities. The Student Estate needed no encouragement at all! It moved onto the streets. And the head of the Minister for Higher Education, rolled in the basket (Devacquet, 1988). The prototype version of the French Evaluative State set out to use institutional and quality review primarily to mobilise the Academic Estate and to persuade it to be bolder in developing new programme provision and innovation. Quality reviews had literally an exemplary purpose: to demonstrate to the Academic Estate those innovative programmes and their achievements, already taken by other Higher Education Institutions in France. In short, quality demonstrated would, hopefully, stimulate institutional boldness and initiative further and equally hopefully, thus become a systemic feature. In this, the French Evaluative State in no way challenged basic concept of higher education as a public service, still less did it depart from the principle that ostensibly guided it since 1968 - that of participant democracy (Neave, 2012, pp. 70-73).

What can we say of this first stage in the developmental saga of the Evaluative State? Briefly stated, Quality was seen as coterminous with efficiency, itself defined in Britain and the Netherlands primarily in budgetary terms. "Doing more for less" was the parrot-cry of the hour.

\section{The Second Stage}

From these pragmatic beginnings in shaping the Evaluative State, both in Europe and Britain, the second stage focused on two key dimensions: the internal refinement of operational procedures and the definition of ownership. Internal procedures 
entailed a detailed and systematic review of individual HEls, a procedure, painstaking, time-consuming and costly. In France, institutional review was broadened to include cross-system reviews of displinary areas, higher education's performance in particular regions. It was an exercise in mapping out, identifying and validating a limited number of indicators that were both discriminatory - in the precise meaning of that term - and sensitive. Benchmarks or standards of expected performance were set in place. In certain systems, for example Sweden, the original 'review cycle' was lightened and converted into a more focused 'alert system', aimed primarily at detailed follow up of those establishments in obvious difficulty (Hogskolverket, 2005).

\section{Ownership: from Honest Broker to Evaluative State}

Despsite differences in pace and timing , the question of ownership or the administrative locus of the Evaluative State marks the transition from Stage 1 to Stage 2. Both in Britain and Portugal, the first steps towards the formally organised Evaluative State, came from university leadership: by the Committee of Vice Chancellors and Principals, in the shape of the Jarratt Report of 1985 (Jarratt Report, 1985) and in Portugal, the Conference of Portuguese Rectors some six years later (Neave, 2012, pp. 131-135). In France, definition of ownership followed a different route. Ownership was vested in the Comité National d'Evaluation, and its independence underpinned by the Comité's reporting on a two yearly basis, not to the Ministry, but to the Head of State. (Neave, 1996, pp. 61-88.) In all three instances, the initial profile of the Evaluative State was that of an "honest broker", a "go between" rather than as Principal in a relationship of Principal to Agent (Neave, 2012, p. 195). In Portugal, the model of honest broker model built explicitly out of Pedagogic Autonomy, which five years previously government had conferred on public sector universities.

Relocation of ownership was a key feature to Stage 2 in the saga of the Evaluative State - a process delicate and protracted in the UK, France and Portugal. Responsibility for refining assessment procedures was subsequently placed in Agencies of Public Purpose: the British Quality Assurance Agency in 1997, and the Portuguese Conselho Nacional de Avalacao do Ensino Superior in 1998. In France, the gradual ousting of the Comite National d'Evaluation from its original status of relative independence was, for reasons we have already gone into, cautious and incremental. Yet, in 2007, the CNE merged with the Association pour l'Evaluation de la Recherche et de I'Enseignement Superieur (AERES) effectively bringing the Comite back into the mainstream of administrative oversight rather than standing to one side as honest broker (Neave, 2012, p.198). 


\section{Sinners to Repentence}

In both France and Portugal, redefinition of ownership and its administrative location received the weight of law, in France with the Law of August 10 th 2007, reorganising the 'new university' and in Portugal, exactly one month later by the Higher Education Guideline Law. From the standpoint of the adepts of Neo-Liberalism and more explicitly, New Public Management, here were two most satisfactory, though belated, examples of 'sinners come to repentence.' Legislation moved higher education in France and Portugal firmly onto the second stage in the saga of the Evaluative State.

\section{The Significance of the Evaluative State}

What has the Evaluative State achieved so far? Where does it fit in that central task which, following the terminology of the late Burton R Clark, is described as 'system coordination' (Clark, 1983) and which today carries the more hierarchical descriptor 'system steering'? It is precisely in the shift of system oversight from coordination to steering that the Evaluative State has left its mark in Continental Europe - but not in the Disunited Kingdom, which arguably has discovered some of the benefits that accompany enhanced central oversight and regulation.

From an historical perspective, system coordination in Europe was formally grounded in elaborate legal codification, regulation and oversight exercised by central - or, in the case of Germany, Provincial and Federal - Ministry. The 'State control' model of coordination rested on what has termed 'principle of legal homogeneity'. As the term implies, legal homogeneity applied uniformly across a particular higher education sector or institutional type (Neave and van Vught, 1991). In turn, coordination itself drew on a number of key assumptions. The most telling may be said to be three:

1. that legal intent was reflected in institutional reality.

2. that change and adaptation at institutional level took place as part of an internal organic process that proceeded from within the twin "freedoms" of teaching and learning.

3. that major system reform which, by definition demanded legislation, was both exceptional and worked out over a period of ten to fifteen years (Neave, 2012, p.13).

The Evaluative State as indeed quality assessment and quality assurance as its prime operational instruments, did not reject these assumptions. Rather, it converted them into hypotheses. These hypotheses required regular, formal and empirical verification. Higher education decision-making, to use an current OECD expression, became 'evidence-based'. In short, the assumption could no longer be made that legal 
intent necessarily brought about immediate institutional "take up". Nor could proof of institutional response be taken for granted once higher education's mission was redefined as meeting the immediate needs of the market, the innovation system or upholding the nation's competitive stance, few of which are constant, most of which change, fluctuate and evolve.

\section{The Evaluative State. What it has done}

What has the Evaluative State achieved? From an historical perspective and one focused on mainland Europe, the impact of the Evaluative State falls likewise in three domains.

First, its procedures have revealed - and that in high detail - an institutional dynamic which, whilst doubtless present before, could not adequately be taken fully and rapidly into account in systems of higher education wholly dependent on the workings of legal homogeneity. Understanding higher education's dynamics no longer rests solely on the presumptions explicit in legal codification.

Second, irrespective of the particular variant that individual systems of higher education have set in place, the Evaluative State turns around the notion of conditionality (Chevaillier, 2004). Like the evaluatory process on which it is based, conditionality is bounded by standardised indicators of expected performance, mediated across different sectors of higher education (Santiago, Carvalho, Amaral \& Meek, 2006, pp.139148). In effect, benchmarking.

Third, the Evaluative State standardised measures of performance. It also standardises the period over which they are assessed. (Neave \& Teixeira, 2012, p. 39) in the shape of the review cycle.

\section{A Supplementary Instrument. The State Evaluative and Evolutive}

From a long-term perspective, the Evaluative State has supplemented an historic mode of administrative control over higher education - legal codification - with a second system of oversight. This second system is built around time-restricted performance and its verification. The overall goals of higher education are today driven primarily by forces external to higher education - competitive demand, the provision of services to the Knowledge Economy, the creation of 'skills' deemed necessary for the well-being of that economy. Last but not least, the generation of appropriate knowledge as the basic capital in that self-same construct of the Knowledge Economy. To the historic principle of legal homogeneity, the Evaluative State added an immensely powerful instrumentality, running parallel to legal codification. It is, moreover, an instrumentality that may adjust or modify its own internal dynamic. And it may do so with relative expedition. 
This it does by setting and, if necessary, resetting or adding to, the range of activities for which accounts may be demanded and rendered. In short, the Evaluative State has created a second form of homogeneity. This key feature of today's form of homogeneity is therefore both evaluative and evolutive.

\section{Conclusion}

This is a partial account. It is so in both senses of the word. It is not the full story. Like most sagas, the Evaluative State has a beginning, but not necessarily a clear end. My account is partial because it brings together the interpretations of one man. But sagas that endure are never the work of a single Master of Tales. They are always taken up, carried forward, elaborated and made more insightful - more valuable still - by fellow scholars and younger colleagues. Let me then use this occasion to express one very real hope: that this very personal Last Hurrah may be both a call to arms, a call for further curiosity. But let it also stand as a very personal and heart-felt "thank you" for your company over the years as well as your attention on this paricular occasion.

Note: This paper is a version of the keynote presented at the $1^{\text {st }}$ Conference of the Portuguese Society of Comparative Education SPCE-SEC, Comparative Education beyond the numbers: Iocal contexts, national realities and transnational processes, held in Lisbon, 26-28 January 2016.

\section{References}

Chevaillier, T. (2004). The Changing Rôle of the State in French higher education: from curriculum control to accreditation. In Schwartz-Hahn, S. \& Westerheijden, D. (Eds.) Accreditation and Evaluation in the European Higher Education Area. Dordrecht: Kluwer Academic Publishers.

Clark, B. R (1986). The Higher Education System; academic organization in a cross-national perspective. Berkeley/Los Angeles/London: University of California Press.

Devacquet, A. (1988). L'Amibe et l'Etudiant: Université et recherche, l'état d'urgence. Paris: Odile Jacob.

Scheele, J. P., Maassen, P. A. M. \& Westerheijden, D. F. [Eds] (1998). To Be Continued...follow up of Quality Assurance in Higher Education. The Hague: Elsevier/De Tijdstroom.

Gayon, V. (2012). Le château de la Muette: enquête sur une citadelle du conformisme intellectuel, Le Monde Diplomatique, juillet, 22-23.

Gray, T.. Elegy in a Country Churchyard. Available at: http://www.thomasgray.org/cgi-bin/display. cgi?text=elcc (consulted Jan $2^{\text {nd }}$ 2016)

Hogskolverket (2005).The Evaluation Activities of the National Agency for Higher Education in Sweden. Final report by the International Advisory Board, 20005:38R. Stockholm, Högskolverket.

Hsieh, C. C. \& Huisman, J. (2017). Higher education policy change in the European higher education area: divergence of quality assurance systems in England and the Netherlands, Research Papers in Education, 32(1), 71-83.doi:http://dx.doi.org/10.1080/02671522.2015.1129645 
Jarratt Report (1985). Steering Committee for Efficiency Studies in Universities, (Chairman Sir Alex Jarrat). London: CVCP.

Kogan, M. \& Kogan, P. (1983). The Attack on Higher Education. London: Kogan Page.

Neave, G. (1996). The Evaluation of the higher education system in France. In R. Cowen [Ed] World Yearbook of Education 1996 The Evaluation of Systems of Higher Education, (pp. 66-81). London: Kogan Page.

Neave, G. (2012). The Evaluative State, Institutional Autonomy and Re-engineering Higher Education in Western Europe: The Prince and his Pleasure. Basingstoke/ New York: Palgrave.

Neave, G. \& Amaral, A. (Eds) (2011). A Nation, a Generation: Higher Education in Portugal 1974 - 2009. Dordrecht: Springer Verlag.

Neave, G. \& van Vught, F. (Eds) (1991). Prometheus Bound: the changing relationship between government and higher education in Western Europe. Oxford: Pergamon Press.

Schwartz-Hahn, S. \& Westerheijden, D. (2004). Accreditation and Evaluation in the European Higher Education Area. Dordrecht: Kluwer.

Staropouli, A. (1987). The Comité national d'évaluation, European Journal of Education, 22 (2), 123-131.

Guy Neave

Director of Research at CIPES, Matosinhos, Portugal. Prior, Professor of Higher Education Policy at the Centre for Higher Education Policy Studies at Twente University, the Netherlands and Director of Research at the Parisbased International Association of Universities.

Email: guy.r.neave@gmail.com

\section{Correspondência}

Guy Neave

CIPES - Centro de Investigação de Políticas de Ensino Superior

R. $1^{\circ}$ de Dezembro 399, 4450-137 Matosinhos

Data de Submissão: Janeiro 2016

Data de Avaliação: Março 2016

Daa de Publicação: Dezembro 2017 